UDC 821. 113.111

DOI https://doi.org/10.32447/2663-340X-2018-4-44-48

\title{
POETIC SINGULARITY OF H. C. ANDERSEN'S NOVEL “ONLY A FIDDLER”
}

\author{
Inha Kapustian \\ PhD in Pedagogical Sciences, Associate Professor in the department \\ of English and German Philology \\ at Poltava V. G. Korolenko National Pedagogical University \\ str. Ostrogradskyi 2, Poltava, Ukraine
}

\begin{abstract}
The article analyzes the features of the poetics of the novel, taking into account the permanent problems in the writer's work, namely the struggle between good and evil. In particular, attention is focused on the skill of creating characters. The author explores the features of plot construction, the role of epigraphs in the functionality of imagoes. The idea of the inseparability of the author's world outlook and the contextual image in the novel is postulated. As a result, coherences of poetics are attested on the basis of philosophical existential problems.In addition to thatthe author goes on with the opinion that the genre of the novel is characterized by its complexity. It combines the features of the adventure and autobiographical novel, which are closely interwoven with fairytale elements and philosophical reflections.

More over the reader is informed that this is a novel about unshared love, imbued with lyricism and symbolism. In the final analysis it is worth saying that $H$. $C$ Andersen includes the real names of the people in the novel, further there are different real episodes inserted in the third part of the novel as the ballet, the author examines kinds of episodes and in the end concludes that this embedded micrograph in the structure of the novel is not accidental. It allows better understanding of the character.The author also discusses the protagonist's decisive character which is based on the writer's description as beautiful, intelligent, but the one who does not imagine her life without wealth, so she marries a Marquis, whom she does not love. She does not worry about virtues; life is a game for her. The reader is informed about the values implicitly with the help of an image of Naomi who is described as a beautiful lady but she does not have a heart.

To cap at all the author admits that each chapter of the novel has well-chosen epigraphs from the works of Voltaire, Schiller, Goethe, Eichendorff, Heine and other authors. All the pictures described in the novel relate to the philosophical problems of the work, in particular, with the eternal problem of struggle between good and evil, between angelic and demonic.
\end{abstract}

Key words: genre, poetics, novel, artistic structure, imago, style.

Introduction. H. C. Andersen is one of the best Danish novelists of the nineteenth century. A wellknown scholar, writer-researcher of his works the literary critic Bo Grønbech noted in his work "H. C. Andersen, levnedsløb, digtning, personlighed" (Hans Christian Andersen, Life, Poetry, Personality, 1971), that during the life of the writer, "his name was placed on the same level as the following European masters as Walter Scott and Victor Hugo" [5]. He was the author of six novels - "The Improvisator" (1834), "O.T." (1836), "Only a Fiddler" (1837), "Two baronesses" (1848), "To be not to be" (1857) and "Lucky Peer". However, in the Slavic countries Andersen is known mainly as a storyteller. His tales were translated and published many times, which cannot be said about his novels. There is still no translation of Andersen's novels into the Ukrainian language.

Brief literary review of the study. The name of H. C. Andersen as a storyteller, novelist, and narrator constantly attracted the attention of literary critics and scholars. Among the most important are the works by L. Yu. Braude, B. Grønbek, G. Brandes, J. Jorgensen, J. Jakobsen. National scientific sources

(C) Kapustian I. Poetic singularity of H. C. Andersen's novel "Only a fiddler" devoted to the detailed analysis of the novel "Only a fiddler" are practically not widely known. Meanwhile, this work was highly appreciated by the Swedish playwright, novelist and poet J. A. Strindberg (engl. Johan August Strindberg,1849-1912) who admitted this work to be a great fairy tale and one of the best in Andersen's authorship. [cit. by: 3].

Setting objectives. The aim of the study is to sketch the outlines of a more differentiated approach towards the understanding of the novel and justify the poetic and contextual features of the novel "Only a fiddler". To achieve the goal we are to fulfill the following tasks: to analyse the critical overview on the discussed issue; to define the peculiarities of the novel and to consider conceptual singularity of the poetic feature of the novel.

Main idea and supporting details presentation. Scientific sources devoted to the detailed analysis of the novel "Only a Fiddler" are practically unfamiliar. Meanwhile, this work was highly appreciated by Swedish writer Augustine Strindberg: "This is a great fairy tale," he wrote, "and one of Andersen's best" [3]. It was contemporary criticism in his native land that was most scathing and unforgiving. Published in 1838 , the work by Danish writer Søren Kierkegaard, Afen Endnu Levendes Papirer (From the Papers of a Person Still Alive). This work is an extended review 
of Andersen's novel "Only a Fiddler", published in 1837. According to Kierkegaard, the fiddler's hopeless struggle is a reflection of Hans Christian Andersen's own grudge against the world: 'Andersen's fundamental idea [is] dissatisfaction with the world:(...) displeased and dissatisfied as he is with the real world, he tries to gain vicarious satisfaction in his own timid poetic creations. Like Lafontaine, therefore, he sits and cries over his unhappy heroes, who are doomed to perish, and why? Because Andersen is the man he is. The same joyless fight that Andersen himself has fought in life is now repeated in his poetry. (HCA Center). Kierkgaard regards Andersen's novel of lacking any real genius and contends he merely bows to the disapproval of others and writes for his critics, thus lacking any real use of talent. He contends that Andersen, like his hero character in Only A Fiddler, is pampered and nurtured instead of schooled by adversity, a fate Kierkegaard saw as his own (HCA Center)/

The genre of the novel is characterized by its complexity. It combines the features of the adventure and autobiographical novel, which are closely interwoven with fairy-tale elements and philosophical reflections. This is a novel about unshared love, imbued with lyricism and symbolism.

The autobiographical character of the novel is due to many factors and circumstances: the author gives to the hero his name - Christian, the act of many chapters of the novel is in the Danish province, the hero's parents, as the parents of Andersen, are poor people. But the main thing - the novel reflected the child's impressions of the author, his impressions from journeys around European countries, as well as his aesthetic and philosophical views. The image of the author plays an important role in the artistic structure of the novel. The main ways of expressing the author's consciousness is the author-narrator and lyrical hero. The novel is full of authorial lyrical reflections, which greatly extend the semantic field of the work, giving it a truly philosophical character.

At the basis of the novel a biographical principle is the main. The action of his first sections takes place in the Danish city of Svendborg Kommune. The author introduces the reader to Christian's parents in the exposition of the work. His father was an ordinary tailor, and his mother, Maria, was a laundress. It is noteworthy that the boy's father, as often happens in fairy tales, is not named after his name, he's just a tailor who loves nature and travel. However, this tailor is not as simple as it may seem at the first glance. His vital interests are not limited to commonplace. This is evidenced by the drawing, or rather, the painting "Reincarnation" made by him, which depicts Dr. Faust, immersed in the reflections on science, as well as the Bible and Satan, who tempts the doctor. The painting had its secrets: having pulled for one cord, the clock turned into Satan. "On one side stands a clock; it is twelve o'clock at night: on the other side lies the Bible. Pull the string, there, on the left. See! the clock changes into a devil, who leads Faust into temptation. Now, we will pull this string on the right, and the Bible opens, an angel comes forth from the leaves and speaks words of peace" - explains the tailor [1]. The plot for his painting was taken by the father of the hero on the trips of Germany. In the context of the novel, the picture of a microscale acquires a symbolic meaning. In a subsequent story, the reader will observe the struggle of the divine and devil in the souls of the heroes of the novel.

An important motif of the novel's exposition is the motif of the house, the symbol of which is storks. The novel begins with the author's reflections that in the spring, when the snow melts, stork returns from a long trip to Denmark, "to his home". In the following story, these birds will be repeatedly mentioned in the text of the novel. They accompany Christian throughout his life. A stork on the roof of the house of a Jewish family's house, in which his granddaughter Naomi lived, a stork in the meadow, which tempted the boy to enter the wide world symbolize a lot from existential universe of the author. At the end of the novel, the reader sees a stork in the house of the hero, the only living creature.

The hero saved the wounded bird, cured it, and it remained with him. The death of the stork, which were defended by stronger birds are the symbol of the social system in which only the strong win, on the other hand, the death portends the death of miserable and sick Christian. The image of stork can be considered as a through image-motive of the work.

There are two compositional centers in the novel, two central images - Christian and Naomi, whose lives are visible, starting at their childhood. Andersen is a master of creating children's character not only in fairy tales. The author himself was considered to be a "a hideous man you could find" as once Clara Schumann wrote about him to Robert Schumann “... he looks most interesting and has a poetic, childish mind...". In the novel "Only a fiddler", he describes in detail how important in the life of the vulnerable boy, Christian, is the girl Naomi, the granddaughter of a Jew who lives in the neighborhood.

Symbolism is imbued through children's games. For example, Naomi, who had "lively green eyes", round cheeks and black curls, offered Christians to sell money, while the money in this game served as petals of flowers. To get them, it was necessary to give something in return, and since Christians had nothing, he had to give Naomi his eyes and lips. The symbolic nature of the episode is that even then, in childhood, trusting and naive Christian loved Naomi and was always ready to give her heart, but she just did not need it.

The destruction of idyll is an episode of a fire in the Jew's house, during which his master died, and only his servant Jul and Naomi's granddaughter remained alive, who was saved by a mysterious Norwegian, Christian's Godfather. The symbolic nature of this episode underlines the death of storks at the Jewish home during the fire. "Upon his parents' house he saw a stork; it was the father-stork, 
that had returned, and could neither find his nest nor the house on which his nest had stood".

When, after the fire, the parents of Christian took an orphan Naomi to her home, the children's games continued. The boy remembered how they played the bride and groom as he kissed a girl. He was Naomi's called brother until thetime she was adopted by a rich duke family.

Starting from this moment, the story lines of the heroes diverge for some period. The author focuses on the most important episodes of Christian's life, including how he visits the house of his godfather, a Norwegian violinist, who teaches the boy to play the violin. Affection and fear are two feelings that Christian feels in his home.

In his novel, Andersen often uses the device ecphrasis. Description of the paintings hanging in the house of the godfather - five parts of the "dancing Death"- is a kind of complement to the psychological portrait of their owner. Looking at these pictures, the boy asks the godfather to play the dance of the Death. These details of the text reinforce the atmosphere of mystery, which shrouded the image of the godfather. We can assume that its creation was influenced by Gothic novels popular in the era of romanticism. So, Chricstian' smother believed that in the game of the godfather there is something from divination. To emphasize the peculiarities of the game of the Norwegian man, the author reflects on the engravings that hung in his house and were brought from Paris. The description of these engravings is an example of intermedialism in the novel. One of them depicted the devil, the other - a place of execution. The devil sat at the top of the pillar, spreading his legs, with the pillar resembling the cross of Calvary. A young girl prayed before the cross, thinking that this is a sanctuary. Commenting on the content of the engraving, the author emphasizes that the same kind of painting, only depicted in the sounds, was a music of the godfather. The motive of the devil's temptation will be repeated continuously in the novel, and it can be considered a leitmotif.

The image of the godfather is ambiguous and mysterious in many things. Christian had a wellknown mystical legend about merman who taught the godfather to play the violin, who later chanted for him, possibly wishing to get his soul, but the godfather hid himself in the church. On the one hand, he is a kind person. It is he who gives Christians his old violin and books, becomes his first teacher, takes Christian to his first journey to Torsång, rescues the boy when he choked in the sea water. A trip to Torsång is connected with another terrible challenge for an inexperienced child. Hiding in the bell tower, he did not have time to leave it until the moment the bells began to call. The boy felt the approach of death and realized that the bells could kill. This feeling of fear, which Andersen depicts with a great skill, has not passed without a trace and has become the cause of Christian's attacks, to get rid of which he helped only a miracle, a miraculous source.
Despite the fact that the godfather was a significant figure in the life of the boy, he did not follow his life's teachings. The things he spoke during one of the meetings did not seem to Mary wicked thoughts, and she felt that the evil spirit she was afraid sat with her at the same table. So, the godfather expressed the idea that in every person the wild beast is hiding and this beast is indestructible and will sooner or later go out. He advised the boy to catch the joy of life when you are young, so that not to regret of not having sins, because he believed the sins in our life is as the salt for food. It was he who told him that it is important to choose the road for life to go.

The author of the novel builds a plot of the laws of the novel of upbringing: to replace one teacher of the hero comes another one. After the godfather Christian teacher was the skipper Peter Vick, who agreed to take him to the boat as a cabin boy. The desire of Christian to get on the schooner was contributed to the fact that Peter Wick had a violin, which Christiancould play.

An important stage in the life of the hero is his staying in Copenhagen, an acquaintance with the city, in which he loses part of his child's illusions. In this city he first visited the theater in which he saw Naomi. The next meeting of the heroes takes place in the girl's house, where Christian penetrated in hope to see her. He loved Naomi as a sister, and she pretended not to be familiar with him. Christian was just a "dirty hunger" for her. These are heroes antipodes in their life's aspirations and ideals.

In the second part of the novel, the paths of heroes are interspersed several times. The fate brings them to a critical moment during the winter trip to Sweden, where Christian went with Peter Vick. They were forced to interrupt their hike, because the ice was broke by the current. Here on the ice between Zealand and Sweden, feeling a sense of fear when the ice cracked under his feet, Christian again saw Naomi, who was riding in a carriage with Earl, his foster father. The author compares the fate of the heroes with the wind: it depends on the direction in which it blows. So far, the fate gives Christians an encounter with a girl whom he remembered and always thought about. Peter Vick's shoe stands in front of the Earl's house, who calls Christian "little musician". Watching for a life in the Earl's House, who has a large library of Goethe, Racine, and Swift books, Christian realized that he and Naomi are at different poles

The author repeatedly confronts the hero with the life realities. An example of this is the episode when a woman's body with golden earrings and amber beads was found near the ship. "His hand glided over the boy's countenance; his fingers touched his throat "Now rides Death over the threads of thy life! Thy soul is pure and innocent, and if there be a state of happiness thou hast a clear title to it, if I involuntarily send thee out of this life. Ah, how little is required to send a soul out of the world! But I will not! May they all suffer 
and be tormented, as I have suffered and been tormented". Here is the motive of love for sale.

An important feature of the composition of the novel is that the exact time of action is indicated. For example, the author reports that at the end of April 1816, Christian arrived to the city of Odense on the island of Fyn to continue learning to play the violin. In this he helped Peter Vick, who wrote letters of recommendation to his friend Knepus. The author sympathizes with his hero, which does not prevent him from being ironic about his being naive.

Conclusions. In the final analysis it is worth saying that H. C. Andersen includes the real names of the people in the novel. In particular, he depicts the appearance of King Louis Philippe of France, surrounded by sons and generals at the opening of the statue of Napoleon on the Vendome Column. The theme of Napoleon has repeatedly arised in conversations between heroes. So, when one of the courtiers notices that Napoleon was boisterous and cold that he looked like Nero, Naomi defended the emperor. There is a big insert episode in the third part of the novel - a description of the ballet "The Temptation of St. Anthony", in which Naomi and Nativity arrived together with the prince. The main motive of the plot is the action "The Temptation of St. Anthony" which struggles between divine and devilish, angelic and demonic. This embedded micrograph in the structure of the novel is not accidental. It allows better understandingof the character.

The author gives Naomi a decisive character. She is beautiful, intelligent, she does not imagine her life without wealth, so she marries a Marquis, whom she does not love. She does not worry about virtues; life is a game for her. At the end of the novel, returning to his native land, she meets the funeral procession, which does not cause her sympathy, because the dead person was only a fiddler. The author does not comment on such a behavior of the heroine, but the reader is clear: she does not have a heart.

To cap at all we must admit that "Only a Fiddler" is written by the talented hand. The brilliancy of the novelist affects not only the creation of characters, the construction of the plot, but also in carefully thought out of the composition. Each chapter of the novel has well-chosen epigraphs from the works of Voltaire, Schiller, Goethe, Eichendorff, Heine and other authors.

The motives of the house, the family and their destruction motives, motives of destiny, meetings and games motives, as well as the description and ecphrasis, play an important role in the structure of novel. All the pictures described in the novel relate to the philosophical problems of the work, in particular, with the eternal problem of struggle between good and evil, between angelic and demonic.

\section{BIBLIOGRAPHY}

1. Андерсен Г. К. Всего лишь скрипач / пер. С. Белокриницкой. М. : Изд-во «Текст». 2001. 352 с. URL: http://www.sky-art.com.

2. Грѐнбек Бо. Г. Х. Андерсен. Жизнь. Творчество. Личность. URL: http://19v-euro-lit.niv.ru/19v-euro-lit/ grenbek-andersen/index.htm

3. Kirstine Marie Kastbjerg. The Danish Gothicof B. S. Ingemann, H. C. Andersen, Karen Blixen and Beyond. A disser ... the degree of Doctor of Philosophy: University of Washington, 2013. $399 \mathrm{c}$.

4. Мацапура В. Роман Г. К. Андерсена «Лише скрипаль»: поетика і контекст. Вісник Харківського національного університету імені В. Н. Каразіна. Серія «Філологія». 2017. Вип. 76, С. 63-67.

5. Andersen J. Hans Christian Andersen a new life. NewYork , 2003. 624 p.

6. Askgaard E. S. Hans Christian Andersen. The fairy tale of Hans Christian Andersen told by Odense City Museum. 2005. Odense City Museum and Grønlund's Forlag.

\section{REFERENCE}

1. Andersen H. C. Vsego lish skripach / per. S. Belokrinitskoi. M.: Izd-vo"Tekst". 2001. 352 c. URL: http://www.sky-art.com. [Only a fiddler]

2. Grionbek Bo. Hans Christian Andersen. Zhyzn. Tvorchestvo. Lichnost. URL: http://19v-euro-lit.niv.ru/19v-eurolit/grenbek-andersen/index.htm [Levnedsløb. Digtning. Personlighed].

3. Kirstine Marie Kastbjerg. The Danish Gothic of B. S. Ingemann, H. C. Andersen, Karen Blixen and Beyond. A disser ...the degree of Doctor of Philosophy: University of Washington, 2013. $399 \mathrm{c}$.

4. Matsapura V. Roman H. C. Andersena "Lyshes krypal": poetyka i kontekst. Visnyk Kharkivskogo Natsionalnogo universytetu imeni V. N. Karazina. Seriia "Filologiia" 2017. Vyp 76, S. 63-67. [H. C. Andersen's novel "Only a fiddler": poetic and context].

5. Andersen J. Hans Christian Andersen a new life. NewYork, 2003. $624 \mathrm{p}$.

6. Askgaard E. S. Hans Christian Andersen. The fairy tale of Hans Christian Andersen told by Odense City Museum. 2005. Odense City Museum and Grønlund's Forlag. 


\title{
СИНГУЛЯТОРНІСТЬ ПОЕТИКИ Г. К АНДЕРСЕНА У РОМАНІ «ЛИШЕ СКРИПАЛЬ»
}

\author{
Капустян Інга Іванівна \\ кандидат педагогічних наук, дочент кафедри англійської та німецької філології \\ Полтавський національний педагогічний університет імені В. Г. Короленка \\ вул. Остроградського, 2, Полтава, Україна
}

У статті проаналізовано особливості поетики роману з урахуванням перманентної проблематики у творчості письменника, а саме боротьби між добром і злом. Зокрема, увагу зосереджено на майстерності створення характерів. Авторка досліджує особливості побудови сюжету, ролі епіграфів у функиіональності імаго. Постулюється ідея про невіддільність авторського світогляду й контекстуального образу у романі. У результаті засвідчено когеренцію поетики на основі філософської екзистенціальної проблематики.

Роман «Всього лише скрипаль» містить у собі риси андерсенівського автобіографічного роману, де чітко простежується тотожність автора та наратора, ретроспективний опис подій власного життя, зображення навколишньої дійсності крізь призму сприйняття наратора, відносність тривіальності або значущості для життя автора подій, щео відбулися, реальність та фактичність зображуваних подій, самоідентифікація автора у світі, саморефлексія над подіями власного життя.

Крім того, автор продовжує думку, щз жанр роману характеризується складністю. Він поєднує у собі риси пригод та автобіографічного роману, які тісно переплітаються з казковими елементами та філософськими роздумами. Більше того, читачу представлено ідею, шо ие роман про нерозділене кохання, який проникнутий ліризмом $i$ символікою. Нарешті варто сказати, що Г. К. Андерсен включає у композиційне тло роману справжні імена людей, більше того, реальні епізоди, які вміщені у третю частину роману. Ці особливості розглядаються $і$ виокремлюються автором як невипадковий вбудований мікрограм у структуру роману. Це дозволяє краще зрозуміти характер твору. Автор також з'ясовує імаго головної героӥні, який базується на описі письменником иього образу як прекрасного, розумного, але таку, яка не уявляє собі життя без багатства, тому вона виходить заміж за маркіза, якого вона не кохає. Ї̈ не турбує доброчесність, порядність та інші чесноти; жстття для неї-гра. Читачу передаються иі ідеї імпліичтно, за допомогою образу Наомі, який описується як прекрасна жінка без «серия».

Взагалі автор визнає, що кожен розділ роману має добре вибрані епіграфи з творів Вольтера, Шиллера, Гете, Гейне та інших авторів. Всі картини, описані в романі, стосуються філософських проблем екзистенції людини, зокрема, вічної проблеми боротьби між добром і злом, між ангельським і демонічним.

Ключові слова: жанр, поетика, роман, художня структура, імаго, стиль. 